\title{
Linkage data for Marfan syndrome and markers chromosomes 1 and 11
}

Jacques de Groote, Peter A Farndon, Michael V Kilpatrick, Anne de Paepe, J W Oorthuys Norman C Nevin, Anne H Child, F Michael Pope

\begin{abstract}
Six large families with classical Marfan syndrome were studied using markers on chromosomes 1 and 11. Two of three families tested showed negative scores using $D 1 S 7$ but a third family gave a positive score $(0.92)$ at $\theta=0.1$. The other chromosome 1 markers typed (MUCI, NGFB, DIS8) excluded close linkage. Negative lod scores with two chromosome 11q22 markers (D11S84, D11S148) excluded at least $20 \mathrm{cM}$ in this area $(Z=<-2)$, which was chosen for study as two enzymes responsible for collagen degradation (collagenase and stromelysin) are localised to this region.
\end{abstract}

Marfan syndrome is a dominantly inherited connective tissue disorder affecting primarily the skeletal, ocular, and cardiovascular systems. The estimated prevalence is $6 / 100000$, with $25 \%$ of cases resulting from new

Dermatology Research Group, Clinical Research Centre, Harrow, Middlesex.

J de Groote, F M Pope

Clinical Genetics Unit, Birmingham Maternity Hospital, Birmingham.

P A Farndon, M V Kilpatrick

Facultair Centrum voor Medische Genetica, Universitair Ziekenhuis, Gent, Belgium.

A de Paepe

Kindergeneeskunde, Academisch Ziekenhuis bij de Universiteit van Amsterdam, The Netherlands.

J W Oorthuys

Department of Medical Genetics, Belfast City Hospital, Belfast.

N C Nevin

Department of Cardiological Sciences, St George's Hospital Medical School, Cranmer Terrace, London SW17 ORE.

A $\mathrm{H}$ Child

Correspondence to Dr Child.

Received for publication 8 September 1989.

Revised version accepted for publication 30 October 1989 mutations. ${ }^{1}$ The gene shows a high penetrance. The condition is heterogeneous ${ }^{2}$ and shows great intrat familial variability of expression.

A typical Marfan syndrome patient is characterise by an asthenic build, being unusually tall with a higR arched palate, long thin extremities, arachnodactyly, chest wall deformities (pectus carinatum, excavatum scoliosis, and joint hypermobility. Common oculas abnormalities range from myopia to bilateral lers dislocation and retinal detachment. Eighty percent have cardiovascular involvement ranging from mitraf valve prolapse to aortic root dilatation and aneurysm? Most of the premature deaths result from aortic dissection, although beta blocker therapy decreases the rate of dilatation of the aortic root, while elective surgical replacement prolongs life, with an $87 \%$ gives year postoperative survival rate. ${ }^{3}$

The primary defect of Marfan syndrome remsing unknown, and no laboratory or prenatal diagnostio test is available. Although many abnormalities connective tissue have been reported, ${ }^{4-7}$ none of tho putative genes coding for major connective tissue fibrillar components has been found to be linked iō family studies. ${ }^{8-12}$

To date, however, the following loci have bee excluded in the families studied: COL1A1, COL1A COL2A1, COL3A1, COL6A1, COL6A2, COL6A3 and tentatively, elastin.

In 1979, Mace's study of 17 families with 19 conventional markers yielded a maximum lod score of 1.38 at $\theta=0.25$ between the rhesus blood group locu on chromosome 1 and Marfan syndrome. ${ }^{13}$

In our present study, we report exclusion data foo four loci on chromosome 1 and two loci on chromos some 11. Linkage studies were performed for si families with classical Marfan syndrome, that is members classically affected in at least two out of three major systems (table 1) with a pedigree showing autosomal dominant inheritance.

The two main enzymes responsible for collage degradation are collagenase (localised to 11q21-q22. 1 q and stromelysin (11q22.2-q22.3). ${ }^{14}$ It is possible that excessive degradation of collagen (and other com ${ }^{3}$ ponents of connective tissue) could be the primary cause of Marfan syndrome. A regulatory gene foi collagenase or stromelysin or both becomes a ne⿻ 

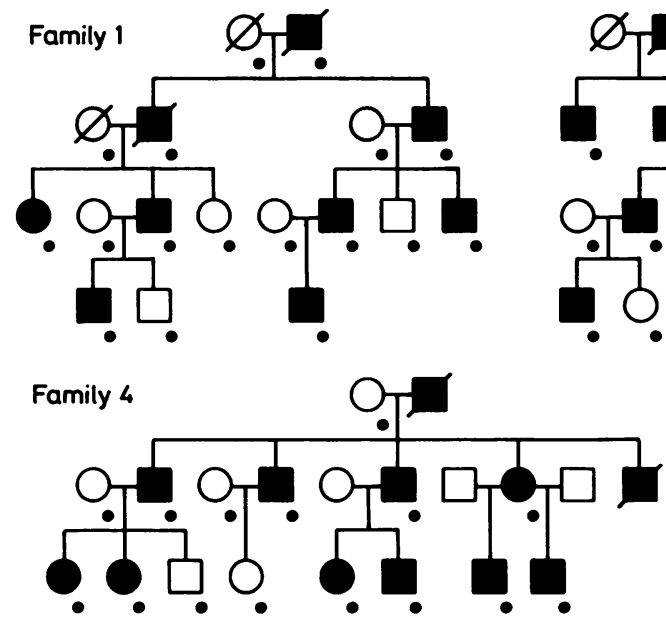

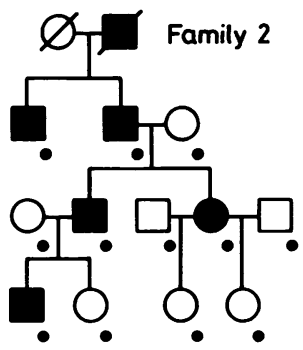

Family 5
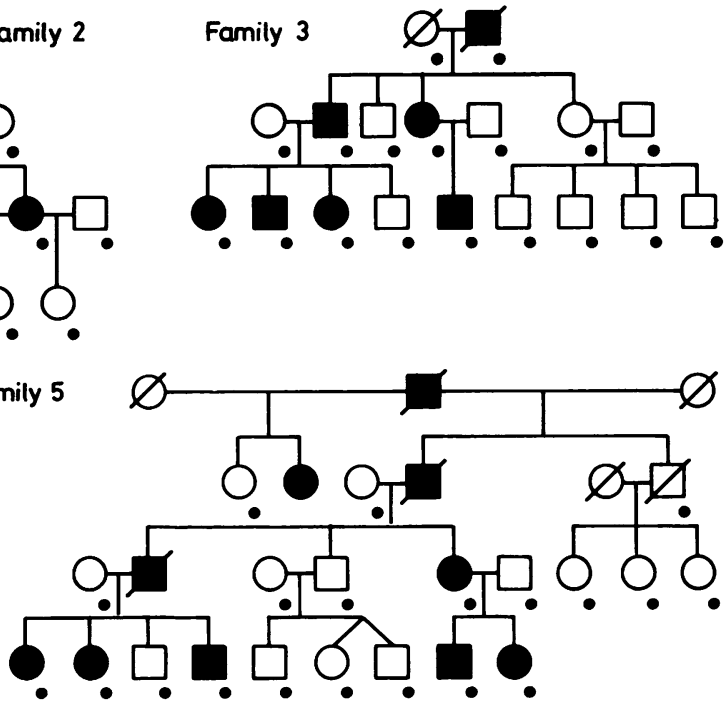

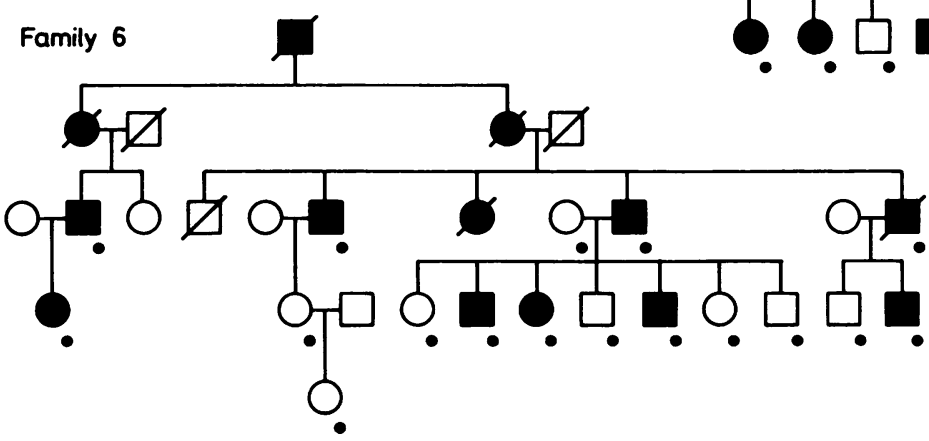

Family pedigrees.

\section{- DNA studied}

Table 1 Cumulative phenotype of six families studied.

\begin{tabular}{|c|c|c|c|c|c|c|}
\hline & & & & & & \\
\hline & 1 & 2 & 3 & 4 & 5 & 6 \\
\hline $\begin{array}{l}\text { Ocular } \\
\text { Ectopia lentis }\end{array}$ & + & + & + & + & + & + \\
\hline Unilateral & + & - & + & + & - & - \\
\hline Bilateral & + & ++ & + & + & + & + \\
\hline Myopia & + & + & + & + & ++ & + \\
\hline Retinal detachment & - & - & - & - & - & - \\
\hline Skeletal & + & + & + & + & + & + \\
\hline Excessive height & + & + & + & + & + & + \\
\hline Arachnodactyly & + & ++ & + & + & ++ & - \\
\hline Chest deformities & + & + & + & ++ & ++ & + \\
\hline Pectus excavatum & + & + & - & + & + & - \\
\hline Pectus carinatum & + & + & + & + & + & + \\
\hline Scoliosis & ++ & + & + & + & + & + \\
\hline Cardiovascular & + & + & + & + & + & + \\
\hline Aortic root dilatation & ++ & + & ++ & + & ++ & + \\
\hline Aortic valve regurgitation & + & + & + & + & + & + \\
\hline Mitral valve prolapse & - & + & + & + & + & + \\
\hline Aortic dissection & + & + & + & + & + & - \\
\hline
\end{tabular}

+ Some of the affected members.

++ All affected members. 
putative gene. Therefore, two probes assigned to 1 lq22 were used for linkage analysis.

\section{Materials and methods}

Six families with classical Marfan syndrome were studied (table 1). The cumulative phenotype of each family includes classical involvement of all three major systems. The difficulty of finding large families with this potentially fatal disease was overcome through international collaboration. Each family was personally examined by one of the authors: family 1 (JWO), family 2 (AdeP), family $3(\mathrm{NCN})$, family 4 (JdeG), families 5 and 6 (AHC).

Ophthalmological and echocardiographic examinations were performed and necropsy reports confirmed where necessary. All children were beyond the stage of expression of the familial phenotype when examined and so were assigned affected or unaffected status. Neither of the two UK families had been included in Mace's original linkage study.

Extraction of DNA from peripheral blood, preparation of probes, and characterisation of RFLPs were performed using standard techniques. Lod scores were calculated by LIPED ${ }^{15}$ assuming full penetrance.

\section{Results}

Sex averaged lod scores for markers that wer $\oplus$ informative and whose results were available when the exclusion map (Blanton $e t$ al, this issue) was compile $\$$ are shown in table 2 . None of the combined lod score was indicative of linkage $\left(Z_{\max }>3.0\right)$, although family 4 showed a score of 0.92 at $\theta=0.1$ with $D 1 S 7$.

\section{Discussion}

It is probable that Marfan syndrome is heterow geneous. To minimise the likelihood of includingseveral subtypes in this study, only fully examined; classically affected families were studied.

The highly polymorphic locus DIS7 was selected because of the previously reported positive loc scores between Marfan syndrome and $R h . D 1 S 7$ ha\$ been shown ${ }^{16}$ to be linked to $R h$ at $\theta \mathrm{m}, \theta \mathrm{f}=0 \cdot 15$ $Z_{\max }=4 \cdot 24$. Two of the three families testedo showed negative scores, but a third family gave a positive score $(0.92)$ at $\theta=0 \cdot 1$. Further families and probes are being typed. The other chromosome $r$ markers typed (MUC1, NGFB, DIS8) all excluded历 close linkage. A hypothetical putative gene, whose function would be to regulate one or both of the twQ main enzymes involved in collagen degradation located

Table 2 Lod scores for linkage between Marfan syndrome and six markers.

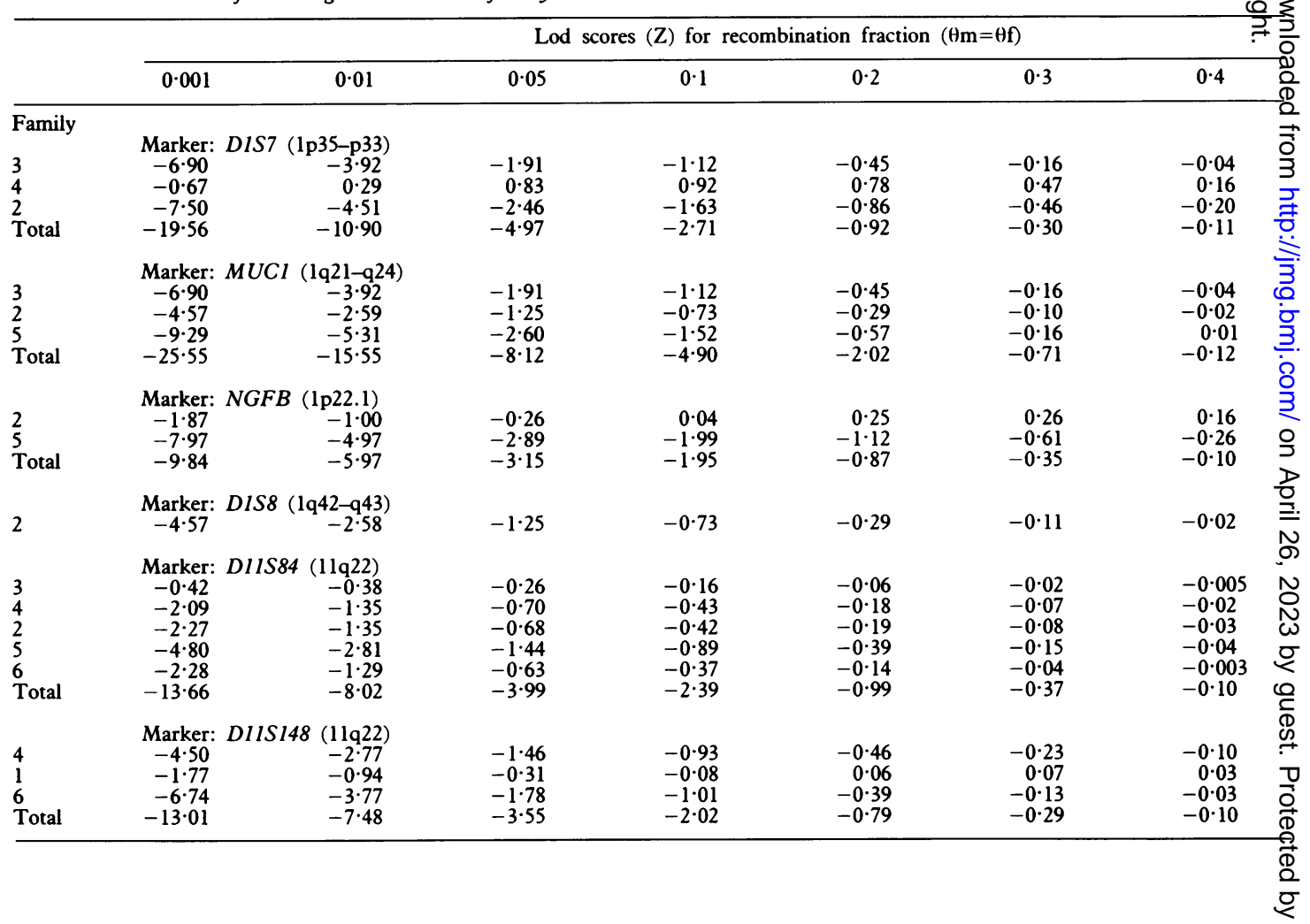


on the long arm of chromosome 11, has not been shown to be linked to the disease.

Negative lod scores with two chromosome 11q22 markers, (D11S84, D11S148 (pYNB)) exclude at least $20 \mathrm{cM}$ in this area $(Z=<-2)$ and perhaps more, although the physical relationships both between the markers and between them and collagenase and stromelysin are uncertain.

Collaboration with other groups is continuing, to avoid duplication of results and to maximise the efficiency of further linkage studies.

This study was supported by the British Heart Foundation (AC), and the Marfan Association UK (J deG). MWK is supported by the Wellcome Trust. We thank the following for the DNA probes; Dr Sylvia Gendler (MUC1), Dr Y Nakamura (D11S148), and Dr J Darby (NGFB). Probes for DIS7 and D1S8 were provided by ICI Diagnostics and D11S84 was obtained from ATCC.

1 McKusick VA. Marfan syndrome. In: Mendelian inheritance in man. 8th ed. Baltimore: Johns Hopkins University Press, 1988:481-3.

2 Pyeritz RE, Murphy EA, McKusick VA. Clinical variability in the Marfan syndrome(s). Birth Defects 1979;XV (5B):155-78.

3 Gott VL, Pyeritz RE, Magovern GJ, et al. Surgical treatment of aneurysms of the ascending aorta in the Marfan syndrome: results of composite-graft repair in 50 patients. $N$ Engl $\mathcal{F}$ Med 1986;314:1070-4.
4 Priest RE, Moinuddin JF, Priest JH. Collagen in Marfan syndrome is abnormally soluble. Nature 1973;245:264-6.

5 Appel A, Horwitz AL, Dorfman A. Cell-free synthesis of hyaluronic acid in Marfan syndrome. F Biol Chem 1979;254: 12199-203.

6 Byers PH, Siegel RC, Peterson KE, et al. Marfan syndrome: abnormal alpha-2 chain in type I collagen. Proc Natl Acad Sci USA 1981;78:7745-9.

7 Boucek RJ, Noble NL, Gunja-Smith Z, Butler WT. The Marfan syndrome: a deficiency in chemically stable collagen cross-links. N Engl F Med 1981;305:988-91.

8 Tsipouras P, Borresen AL, Bamforth S, Harper PS, Berg K. Marfan syndrome: exclusion of genetic linkage to the COL1A2 gene. Clin Genet 1986;30:428-32.

9 Dalgleish R, Hawkins JR, Keston M. Exclusion of the $\alpha 2(I)$ and the $\alpha$ (III) collagen genes as the mutant loci in a Marfan syndrome family. F Med Genet 1987;24:148-51.

10 Ogilvie DJ, Wordsworth BP, Priestley LM, et al. Segregation of all four major fibrillar collagen genes in the Marfan syndrome. Am F Hum Genet 1987;41:1071-82.

11 Francomano CA, Streeten EA, Meyers DA, Pyeritz RE. Marfan syndrome: exclusion of genetic linkage to three major collagen genes. Am F Med Genet 1988;29:457-62.

12 Huttunen K, Kaitila I, Savolainen A, Palotie A, Peltonen L. The linkage analysis with RFLP markers of elastin and type III collagen in Finnish Marfan families. Am f Med Genet 1989;30: $244 \mathrm{~A}$.

13 Mace $\dot{M}$. A suggestion of linkage between the Marfan syndrome and the rhesus blood group. Clin Genet 1979;16:96-102 .

14 Spurr NK, Gough AC, Gosden J, et al. Restriction fragment length polymorphism analysis and assignment of the metalloproteinases stromelysin and collagenase to the long arm of chromosome 11. Genomics 1988;2:119-27.

$15 \mathrm{Ott} \mathrm{J}$. Estimation of the recombination fraction in human pedigrees: efficient computation of the likelihood for human linkage studies. Am f Hum Genet 1974;26:588-97.

16 Farndon PA, Simmons J, Kilpatrick MW. Exclusion data for the naevoid basal cell carcinoma syndrome on chromosome 1 . Cytogenet Cell Genet 1989;51:997. 